\title{
Sources of sodium in the Finnish diet
}

\author{
PIRJO PIETINEN
}

University of Helsinki, Department of Nutrition, 00710 Helsinki 71

Abstract. The purpose of this report was to study all available information for estimating the sources of naturally occurring sodium and added salt in the Finnish diet. The calculations were based on food consumption statistics, sales figures of salt, salt use in the Finnish food industry and catering, and on the food consumption data provided by the mobile clinic dietary survey of 1973-1976.

The average daily per capita intake of added salt is $10-11 \mathrm{~g}$ and that of the naturally occurring sodium in foodstuffs is $0.6 \mathrm{~g}$ which is equivalent to $1.5 \mathrm{~g}$ of $\mathrm{NaCl}$, the total intake being $11-12 \mathrm{~g}$. In the adult population the mean daily intake of sodium expressed as $\mathrm{NaCl}$ is $12-15 \mathrm{~g}$ in men and $10-12 \mathrm{~g}$ in women. The average salt concentration in the diet is $4.3 \mathrm{~g} / 1000 \mathrm{kcal}(10.3 \mathrm{~g} / 10 \mathrm{MJ})$ and that of adults $4.5 \mathrm{~g} / 1000 \mathrm{kcal}(10.6$ $\mathrm{g} / 10 \mathrm{MJ})$.

Of the total sodium intake $50 \%$ is derived from the salt used by the food industry and in catering, $38 \%$ from salt added by the consumer at home, and $12 \%$ from the naturally occurring sodium in the foodstuffs. Of the added salt, $57 \%$ is used by the food industry and catering and $43 \%$ by the consumer. Of the different food items, baked products (bread, buns and pastries) are the most important sources of sodium, constituting $22 \%$ of the total sodium intake. The share of bread alone is $16 \%$ and that of sausages and other meat products is $14 \%$. The share of other food items is less than $10 \%$.

\section{Introduction}

As the importance of sodium intake in the etiology and treatment of high blood pressure has become a matter of dispute during the last decade (MORGAN et al. 1979, SIMPSON 1979) it has become more evident that information on the amounts and sources of sodium in the diet is scarce. Previously the main source of sodium, the common salt, was not considered interesting except as a carrier of iodine (HIILESMAA 1977).

A reason for the lack of data on sodium intake was also methodological. There are no sales statistics on salt in Finland. Traditional nutrition surveys have not provided information on salt because of methodological problems. Only the medical studies on salt and hypertension have included sodium analyses of urine collections and have gradually provided information on the sodium intake of different populations (TUOMILEHTO et al. 1978, 1980).

The importance of knowing the sources of sodium in the diet has become more evident as general sodium intake reduction has been recommended by the United States Senate (ANON. 1977), the World Health organization (ANON. 1978a, 1979 
d), and by Finnish expert groups (ANON. 1978 b, 1981 b). Attention has also been paid to the consumer's possibilities for reducing his sodium intake, since the role of the food industry and catering has grown rapidly. The term "discretionary use of salt" has been introduced to the discussion (ANON. 1979 a). This means the share of salt intake which is under the consumer's own control, the rest being nondiscretionary and out of his direct control.

The purpose of this article was to collect all available statistical and other data that could be used for estimating the per capita intake of naturally occurring sodium and added salt and for finding out their sources in the Finnish diet.

\section{Sources of information}

The consumption figures for different foodstuffs were mainly based on the Balance sheets for food commodities of 1980 (ANON. 1981 a). In addition to this, the consumption figures for different meat products were based of the calculations by HANNUKAINEN (1981) and those of all cereal products were according to SALOVAARA (1981). The sodium content of raw food items was based on the Finnish mineral element composition tables (VARO 1981), and the sodium content of manufactured and prepared foods (expressed as $\mathrm{NaCl}$ ) was based on the information given by various Finnish food manufacturers and research laboratories. Information on the sodium content of Finnish drinking water was requested from the National Board of Waters.

Since there are no sales statistics concerning common salt, a survey was done in spring 1981 covering all the agents and packing and whole-sale firms dealing with salt in Finland. They were asked to report their sales figures for 1980 in as much detail as possible, keeping different types and package sizes of salt separate.

The Household survey of 1976 done by the Central Statistical Office of Finland provided also information on the consumption of salt in households (ANON. $1979 \mathrm{c}$ ). The survey comprised 9034 households recording all purchases including common salt during one month.

The Finnish Food Industries Federation made a survey on the salt use in the food manufacturing industry in spring 1981 (ANON. 1981 d). All food producers except bakeries and small local fish salting and smoking firms were sent a detailed questionnaire concerning the types and amounts of food items produced and the use of salt and some other ingredients in these foods. Domestic sales were requested separately, which formed the basis for calculating the total per capita salt intake derived from foods produced by the Finnish food industry. Information on catering was based on a large study by SITRA (ANON. 1979 b).

Information was also provided by the dietary survey done in connection with the mobile clinic health screening examination of the Finnish Social Insurance Institution from 1973 to 1976 (SEPPÄNEN et al. 1981). The survey comprised 2008 men and 1916 women between 30 and 80 years of age in different regions of Finland. The food consumption data were collected by using the diet history method. For the purpose of estimating salt intake the original food consumption data were grouped into different types of food items and the average salt concentrations of these food items were then used to calculate the salt intake. 
Naturally occurring sodium and added salt in the diet

\section{Naturally occurring sodium}

The daily per capita intake of naturally occurring sodium was based on the consumption of unprepared natural foodstuffs (Table 1). Each food consumption figure is the total amount, part of which is eaten as such, the rest being further manufactured into various food products. The total daily per capita intake of sodium was about $600 \mathrm{mg}$ which is $1.5 \mathrm{~g}$ expressed as $\mathrm{NaCl}$. The main source of naturally occurring sodium was milk, constituting over half of the total amount. Water was not included in this estimate, since its sodium concentration is generally below $10 \mathrm{mmol} / \mathrm{l}$ with only a few exceptions. So it was corsidered an insignificant source of sodium.

\section{Use of salt in bousebolds, the food industry and in catering}

According to the salt marketing firms the total amount of salt sold to households (package size $1 \mathrm{~kg}$ or smaller) was 8332 tons in 1980 which is $4.8 \mathrm{~g} /$ capita/day (Table 2). Most of it was regular table salt (73\%), $21 \%$ sea salt, $6 \%$ Mineral Salt ${ }^{R}$, the share of coarse vacuum salt being under one per cent.

The total amount of salt sold to the food industry and for catering ( 25 and 50 $\mathrm{kg}$ sacks) was 20307 tons, which is $11.6 \mathrm{~g} /$ capita/day. Since the marketing firms were not able to separate accurately the sea salt sold to the food industry from that

Table 1. Naturally occurring sodium in the Finnish diet.

\begin{tabular}{lccc}
\hline Food groups & $\begin{array}{c}\text { Consumption } \\
\text { g/person/day }\end{array}$ & $\begin{array}{c}\mathrm{Na} \\
\mathrm{mg} / 100 \mathrm{~g}\end{array}$ & $\begin{array}{c}\text { Total } \\
\mathrm{Na} \mathrm{mg/person} / \text { day }\end{array}$ \\
\hline Milk & 830 & 45 & 373 \\
Grain & 203 & 1 & 2 \\
Meat & 180 & 60 & 107 \\
Fish & 43 & 60 & 26 \\
Eggs & 32 & 120 & 38 \\
Potatoes & 163 & 2 & 3 \\
Vegetables & 70 & 30 & 21 \\
Fruit and berries & 260 & 2 & 47 \\
\hline Total & & & 617 \\
\hline
\end{tabular}

Table 2. Amount of salt sold to households and the food industry and for catering in 1980 ( $1000 \mathrm{~kg})$.

\begin{tabular}{lcc}
\hline Type of salt & $\begin{array}{c}1 \mathrm{~kg} \text { or smaller } \\
\text { packages }\end{array}$ & $\begin{array}{c}25 \text { or } 50 \mathrm{~kg} \\
\text { sacks }\end{array}$ \\
\hline Regular table salt & 6054 & - \\
Fine vacuum salt & - & 4780 \\
Coarse vacuum salt & 73 & - \\
Sea salt & 1736 & 15526 \\
Mineral Salt & 469 & 20307 \\
\hline Total & 8332 & 1 \\
\hline
\end{tabular}


sold for other purposes e.g. for curing hides or preserving hay, this figure cannot be considered very reliable.

According to the household survey the average amount of salt purchased was $6.6 \mathrm{~g} /$ person/day. Farmers had purchased the greatest amount, $12.1 \mathrm{~g}$, and employees the least, $4.9 \mathrm{~g}$. Since salt is not purchased frequently and the bookkeeping period in the survey was only one month, results obtained by this method are not very reliable. So the consumption figure provided by the sales statistics, 4.8 $\mathrm{g} /$ person/day, is considered to be a better basis for estimating the home use of salt.

According to the survey of the Finnish Food Industries Federation the total amount of salt in domestically produced manufactured foodstuffs was 5890 tons in 1980 , which is $3.5 \mathrm{~g} /$ person/day. Since bakeries were not included in the survey, salt used in their products has to be added to this figure. Based on the calculations by SALOVAARA this is 1.8 per person per day. So the total amount of added salt derived from domestically manufactured foods can be estimated to be 5.3 $\mathrm{g} /$ person/day.

Catering provides 2.2 million meals per day which means 0.46 meals/person/day. The average salt content of a meal can be estimated to be about 3 $\mathrm{g}$. So the amount of salt from this source would be $1.4 \mathrm{~g}$. However, some of the food items in the meals are already prepared by the food industry, e.g. sausages, gravy and sauce mixes and some meat and fish foods. So the amount of salt actually added in catering is smaller, being probably close to $1 \mathrm{~g}$.

\section{Sodium and salt derived from different food items}

The daily per capita consumption figures of different foodstuffs in 1980 is presented in Table 3 . The naturally occurring sodium content of those foods having no added salt is presented as such and is then converted to $\mathrm{NaCl}$ for the total calculation. The sodium chloride concentration in manufactured foods includes also the natural sodium in the product since it was not possible to separate them accurately. Also, other sodium-containing food ingredients other than salt (e.g. leavening agents) are included in the figures.

The total daily per capita intake of sodium calculated this way is $6.9 \mathrm{~g}$ $\mathrm{NaCl} /$ person/day. When the salt used in households $(4.8 \mathrm{~g})$, and in catering $(1 \mathrm{~g})$ are added to this, the total estimated daily per capita intake of sodium expressed as $\mathrm{NaCl}$ is $12.7 \mathrm{~g}$.

The daily per capita intake of energy is according to the food balance sheets $12.3 \mathrm{MJ}(2936 \mathrm{kcal})$. Based on the total salt intake of $12.7 \mathrm{~g}$, the energy-adjusted salt intake or the salt concentration of the Finnish diet is $10.3 \mathrm{~g} \mathrm{NaCl} / 10 \mathrm{MJ}$ or 4.3 $\mathrm{g} / 100 \mathrm{kcal}$.

Food items have been grouped together in Table 4 to find out their importance as sources of sodium in the diet. Bread constitutes $16 \%(2.0 \mathrm{~g})$ and other baked products (buns and pastries) $6 \%(0.8 \mathrm{~g})$ of the total sodium intake. These figures include also home-baking, and the estimated amounts derived from home-baked bread are $0.6 \mathrm{~g}$ and in home-baked buns and pastries $0.4 \mathrm{~g} \mathrm{NaCl}$. So the total share of baked products is $22 \%$. Sausages and other meat products constitute $14 \%$ of the total sodium intake. All the other food items are of less importance. The share of sodium derived from salt used in food preparation in households, $3.8 \mathrm{~g}$ (excluding baking), is $30 \%$. 
Table 3. Average daily per capita intake of sodium chloride based on food consumption statistics.

\begin{tabular}{lrrrr}
\hline Food items & $\begin{array}{r}\text { Consumption } \\
\text { g/person/ } \\
\text { day }\end{array}$ & $\begin{array}{r}\mathrm{Na}^{\mathrm{mg}} / 100 \mathrm{~g} \\
\mathrm{mg} / 100 \mathrm{~g}\end{array}$ & $\begin{array}{r}\mathrm{NaCl} \\
\mathrm{mg} / \text { person/ } \\
\text { day }\end{array}$ \\
\hline Liquid dairy products & 746 & 45 & 112 & 836 \\
Milk powder & 8 & 460 & 1150 & 92 \\
Cheese & 18 & - & 1400 & 252 \\
Butter & 32 & - & 1700 & 544 \\
Margarine & 23 & - & 1700 & 391 \\
Other fats & 9 & - & - & - \\
Commercially baked bread & 92 & - & 1500 & 1380 \\
Commercially baked buns and pastries & 47 & - & 850 & 400 \\
Cereal grain & 120 & 1 & 2 & 2 \\
Cooked sausages & 73 & - & 2000 & 1460 \\
Dry fermented sausages & 3 & - & 4000 & 120 \\
Whole meat products & 7 & - & 2600 & 182 \\
Ready-made meat foods & 16 & - & 1200 & 192 \\
Fresh meat & 82 & 60 & 150 & 123 \\
Salted and smoked fish & 3 & - & 8000 & 240 \\
Preserved fish & 5 & - & 6000 & 300 \\
Ready-made fish foods & 0.4 & - & 900 & 4 \\
Fresh fish & 36 & 60 & 150 & 54 \\
Eggs & 32 & 120 & 300 & 96 \\
Potatoes & 163 & 2 & 5 & 8 \\
Fresh vegetables & 58 & 30 & 75 & 44 \\
Canned vegetables & 12 & - & 600 & 72 \\
Fruit and berries & 260 & 2 & 5 & 13 \\
Sugar, honey, syrup & 105 & - & - & - \\
Sweets & 16 & - & 200 & 32 \\
Mineral waters and soft drinks & 110 & - & 20 & 22 \\
Alcohol & 200 & - & 10 & 20 \\
\hline Total & & & & 6879 \\
\hline
\end{tabular}

- Total $\mathrm{Na}$ concentration expressed as $\mathrm{NaCl}$.

Table 4. The most important sources of sodium in the Finnish diet.

\begin{tabular}{lcc}
\hline & $\begin{array}{c}\mathrm{NaCl} \\
g / \text { person/day }\end{array}$ & $\begin{array}{c}\text { \% of the } \\
\text { total intake }\end{array}$ \\
\hline Milk and milk products & 1.2 & 9 \\
Butter and margarine & 0.9 & 7 \\
Bread & 2.0 & 16 \\
Buns and pastries & 0.8 & 6 \\
Sausages and other meat products & 1.8 & 14 \\
Fish products & 1.0 & 8 \\
Salt used in households* & 3.8 & 30 \\
Salt used in catering & 1.0 & 8 \\
Other sources of sodium & 0.2 & 2 \\
\hline Total & 12.7 & 100 \\
\hline
\end{tabular}

- Salt used in baking $(1 \mathrm{~g})$ is not included in this figure but has been taken into account in bread, buns and pastries. 
Table 5. Estimated daily per capita intake of natural sodium and added salt.

\begin{tabular}{lccrc}
\hline Sources of sodium & $\mathrm{Nag}$ & $\mathrm{NaCl} g$ & $\begin{array}{c}\% \text { of total } \\
\mathrm{Na} \text { intake }\end{array}$ & $\begin{array}{c}\% \text { of added } \\
\mathrm{NaCl}\end{array}$ \\
\hline Natural sodium in foods & 0.6 & 1.5 & 12 & - \\
Salt used in households & - & 4.8 & 38 & 43 \\
Salt used in food industry & - & 5.3 & 42 & 48 \\
Salt used in catering & - & 1.0 & 8 & 9 \\
\hline Total & 0.6 & 12.6 & 100 & 100 \\
\hline
\end{tabular}

Table 6. Mean daily salt intake from different food items among men and women in the mobile clinic dietary survey of 1973-76.

\begin{tabular}{|c|c|c|c|c|c|}
\hline \multirow[t]{2}{*}{ Food items } & \multirow{2}{*}{$\begin{array}{c}\mathrm{NaCl}^{*} \\
\mathrm{~g} / 100 \mathrm{~g}\end{array}$} & \multicolumn{2}{|c|}{ Daily consumption $\mathrm{g}$} & \multicolumn{2}{|c|}{$\begin{array}{l}\text { Daily } \mathrm{NaCl} \text { intake } \\
\mathrm{mg}\end{array}$} \\
\hline & & $\begin{array}{r}\text { Men } \\
(n=2008)\end{array}$ & $\begin{array}{r}\text { Women } \\
(n=1916)\end{array}$ & $\begin{array}{r}\text { mg } \\
\text { Men }\end{array}$ & Women \\
\hline Liquid dairy products & 0.1 & 914 & 664 & 914 & 664 \\
\hline Cheese & 1.3 & 15 & 14 & 195 & 182 \\
\hline Butter & 1.7 & 41 & 23 & 697 & 391 \\
\hline Margarine & 1.7 & 9 & 7 & 153 & 119 \\
\hline Other fats & - & trace & trace & - & - \\
\hline Rye bread & 1.6 & 133 & 96 & 2128 & 1536 \\
\hline Hard bread & 2.2 & 6 & 5 & 132 & 110 \\
\hline Other breads & 1.3 & 51 & 35 & 663 & 455 \\
\hline Pasties & 1.3 & 7 & 7 & 91 & 91 \\
\hline Buns and pastries & 0.8 & 59 & 50 & 472 & 472 \\
\hline Breakfast cereals & 2.3 & 0.2 & 0.3 & 5 & 7 \\
\hline Porridges and gruels & 0.6 & 180 & 132 & 1080 & 792 \\
\hline Cooked sausages & 2.0 & 62 & 33 & 1240 & 660 \\
\hline Dry fermented sausages & 4.0 & 3 & 2 & 120 & 80 \\
\hline Sausage dishes & 2.0 & 12 & 10 & 240 & 200 \\
\hline Salted fish & 12.0 & 10 & 6 & 1200 & 720 \\
\hline Smoked fish & 5.0 & 10 & 7 & 500 & 350 \\
\hline Fish dishes & 1.5 & 28 & 22 & 420 & 330 \\
\hline Egg dishes & 1.4 & 8 & 6 & 112 & 84 \\
\hline Salted mushrooms & 5.0 & 0.3 & 0.2 & 15 & 10 \\
\hline Mushroom dishes & 1.5 & 2 & 3 & 30 & 45 \\
\hline Meat dishes & 1.5 & 158 & 112 & 2370 & 1680 \\
\hline Sauces and gravies & 1.0 & 34 & 20 & 340 & 200 \\
\hline \multicolumn{6}{|l|}{ Boiled potatoes, rice, } \\
\hline macaroni & 0.6 & 22 & 25 & 132 & 150 \\
\hline \multicolumn{6}{|l|}{ Mashed potatoes and } \\
\hline potato dishes & 0.9 & 36 & 26 & 333 & 234 \\
\hline Raw vegetables & - & 44 & 69 & - & - \\
\hline Vegetable dishes & 0.6 & 25 & 29 & 150 & 174 \\
\hline Fruit and fruit dishes & - & 94 & 134 & - & - \\
\hline Berries and berry dishes & - & 79 & 81 & - & - \\
\hline Beverages & - & 920 & 738 & - & - \\
\hline Sugar etc. & - & 31 & 21 & - & - \\
\hline Total & & 2994 & 2377 & 13732 & 9736 \\
\hline
\end{tabular}

- Total $\mathrm{Na}$ concentration excpressed as $\mathrm{NaCl}$. 


\section{Discretionary use of salt}

The estimated daily intake of added salt consists of salt used in households (4.8 $\mathrm{g})$, in the food industry $(5.3 \mathrm{~g})$ and in catering $(1.0 \mathrm{~g})$ totalling $11.1 \mathrm{~g}$ per capita. When the naturally occurring sodium, $0.6 \mathrm{~g} \mathrm{Na}$ or $1.5 \mathrm{~g} \mathrm{NaCl}$, is added to this, the total daily per capita sodium intake is $12.6 \mathrm{~g}$ expressed as $\mathrm{NaCl}$ (Table 5). Only the home use of salt is in the consumer's control and this discretionary use of salt is 38 $\%$. The rest of the sodium comes from added salt used by the food industry ( $42 \%$ ) and from the naturallyoccurring sodium $(12 \%)$. Of the added salt, the food industry controls $48 \%$, the consumer $43 \%$ and catering $9 \%$.

\section{Estimates based on the dietary survey}

The food consumption data of men and women participating in the mobile clinic nutrition survey in 1973-1976 has been grouped into different food items in Table 6. Based in this rough method, the mean salt intake of men was $13.7 \mathrm{~g}$ and that of women $9.7 \mathrm{~g}$. The mean energy intake levels were $3080 \mathrm{kcal}(12.9 \mathrm{MJ})$ and 2170 kcal $(9.1 \mathrm{MJ})$ respectively. The salt concentration in the diets of both men and women was $4.5 \mathrm{~g} / 1000 \mathrm{kcal}(10.6 \mathrm{~g} \mathrm{NaCl} / 10 \mathrm{MJ})$.

As sources of salt the most important food items were baked products (bread, buns and pastries) constituting $3.5 \mathrm{~g}$ of $\mathrm{NaCl}$ in men $(25 \%$ of the total salt intake) and $2.7 \mathrm{~g}$ in women $(27 \%)$. The amount of salt derived from bread was $2.9 \mathrm{~g}$ in men $(21 \%)$ and $2.1 \mathrm{~g}$ in women $(22 \%)$, that from sausages $1.6 \mathrm{~g}(12 \%)$ and $0.9 \mathrm{~g}$ $(10 \%)$, and from salted and smoked fish $1.7 \mathrm{~g}(12 \%)$ and $1.1 \mathrm{~g}(11 \%)$, respectively.

The total amount of salt derived from foodstuffs eaten as prepared dishes was $5.0 \mathrm{~g}$ in men $(36 \%)$ and $3.7 \mathrm{~g}$ in women $(38 \%)$. This can be considered a rough estimate of the salt used at home and in catering. The rest of the salt, $8.7 \mathrm{~g}$ in men $(64 \%)$ and $6.0 \mathrm{~g}$ in women $(62 \%)$ came from all the other food items which are mostly prepared by food manufacturers.

\section{Discussion}

The level of accuracy of these estimates presented in this report can only be considered as rough. For instance waste has not been taken into consideration in any of the food consumption figures. However, since the estimates based on the dietary survey were in good accord with the ones based on food and salt consumption figures, gross errors are very unlikely. The sodium and salt concentrations used are rough averages since great variation exists in the saltiness of meals for example. The available information with its weaknesses seemed, however, to be sufficient in getting the overall picture of sodium and salt in the diet.

Based on food consumption statistics and the sales figures of salt the average daily per capita sodium intake is $12.6-12.7 \mathrm{~g}$ expressed as $\mathrm{NaCl}$. Since no waste in the food consumption has been taken into account, this figure may be slightly high. Assuming that waste is about $10 \%$, the real per capita salt intake is $11-12$ $\mathrm{g} /$ day. Based on the food consumption data collected in the dietary survey the mean intake of salt in adult men is about $13-14 \mathrm{~g}$ and in women $10 \mathrm{~g}$. 
These figures are in good agreement with the results obtained in studies on the sodium excretion of the Finnish adult population. The mean 24-hour sodium excretion of men between 14 and 65 years of age in Kuopio and North Karelia counties was found to be $215 \mathrm{mmol}$ which is $12.6 \mathrm{~g}$ expressed as $\mathrm{NaCl}$, and that of women was $173 \mathrm{mmol}(10.1 \mathrm{~g} \mathrm{NaCl})$ (TUOMILEHTO et al. 1981). Since the sodium excretion is about $90-95 \%$ of the intake (ANON. 1979 d), the actual intake figures are slightly higher. The sodium output of men over 30 in Kuopio and North Karelia counties was $13.2 \mathrm{~g} \mathrm{NaCl}$ and that of women $10.6 \mathrm{~g}$, which figures are very close to the ones obtained from the dietary data.

The estimates on the use of salt in households vary between 3 and 5 grams. On the average $4.8 \mathrm{~g}$ of table salt per person per day is sold in small packages but not all of it is actually eaten because some is left in boiling water etc. In a study where the consumption of table salt was measured over a four-month period in ordinary families, the consumption was found to be only $3 \mathrm{~g} /$ person/day (PIETINEN et al. 1981). According to the dietary survey the amount of salt used in food preparation was about 4-5 g in adults. About one gram of this was estimated to be used in catering but it is compensated by the one gram used in home-baking which was not included in the figure. There are no estimates on the amounts of salt used for salting foodstuffs such as fish or mushrooms.

The discretionary use of salt was on the average $38 \%(4.8 \mathrm{~g} \mathrm{NaCl})$ of the total sodium intake, salt used in the food industry $42 \%(5.3 \mathrm{~g})$ and that used in catering $8 \%(1.0 \mathrm{~g})$. Only $12 \%$ of the total sodium intake was derived from the naturally occurring sodium in foodstuffs $(1.5 \mathrm{~g})$. Of the added salt, the consumer controls about $43 \%$ and the food industry and catering $57 \%$. These figures can be compared to those reported from the United States, Great Britain and Sweden.

In the United States, the Select Committee on GRAS (Generally Regarded As Safe) Substances estimated that the average total daily intake of sodium was between 10 and $12 \mathrm{~g}$ expressed as sodium chloride (ANON. $1979 \mathrm{a}$ ). Discretionary use accounted for 3.4 to $6.5 \mathrm{~g}$, and sodium chloride and other sodium-containing ingredients added during commercial processing about 4 to $6 \mathrm{~g}$. The salt content of the diet was estimated to be about $4.4 \mathrm{~g} / 1000 \mathrm{kcal}$.

In the United Kingdom the range of estimated values for average total daily salt intake is between 11.9 and $13.4 \mathrm{~g}$ with 3.1 to $3.6 \mathrm{~g}$ provided by discretionary salt addition (ANON. $1981 \mathrm{c}$ ). The estimated contribution of sodium from sodiumcontaining food ingredients other that salt is about $5 \%$ of the total intake.

In Sweden the average daily sodium intake has been estimated to be only about $8 \mathrm{~g}$ of $\mathrm{NaCl}$ (WESTIN 1980). Of this amount, $8 \%$ is derived from naturally occurring sodium in foods eaten without added salt (such as milk and fresh vegetables etc.), and $47 \%$ comes from foods produced by the food industry and 45 $\%$ from home-made foods.

The Finnish estimates seem to be similar to the American and British ones. Even the average salt concentration of the diet, $4.3 \mathrm{~g}, 1000 \mathrm{kcal}$ is close to the American estimate $4.4 \mathrm{~g} / 1000 \mathrm{kcal}$.

The most important food item as a sources of sodium in the Finnish diet is bread constituting $16 \%$ of the total sodium intake on the average and about $20 \%$ in the adult population. All baked products form about one fourth of the total sodium intake. Sausages and other meat products constitute about $14 \%$ and fish products $8-12 \%$ of the sodium in the diet. Of the prepared foods, meat and sausage dishes 
are the most important sources of sodium, constituting about $20 \%$ of the total intake and about half of the salt used in food preparation.

Unfortunately there are no calculations of the contribution of sodium from sodium-containing food ingredients other than salt such as baking soda or phosphates because all the data is based on total sodium or sodium chloride analyses. The British estimates, however, show that they are of less importance.

Knowing the main sources of salt in the diet becomes a matter of importance if a reduction in the total sodium intake is recommended. Even though there is no evidence of the benefits of salt intake reduction at the population level, recommendations to reduce salt consumption have been given by some health authorities even in Finland. The National Blood Pressure Committee (ANON. 1978 b) suggested a reduction to $6-8 \mathrm{~g}$, and the Nutrition Committee (ANON. $1981 \mathrm{~b}$ ) suggested a maximum of $8-9 \mathrm{~g}$ or $9 \mathrm{~g} / 10 \mathrm{MJ}(3.8 \mathrm{~g} / 1000 \mathrm{kcal})$. Compared to these, the average sodium intake level of $11-12 \mathrm{~g} \mathrm{NaCl}$ or $4.3 \mathrm{~g} / 1000 \mathrm{kcal}(10.3$ $\mathrm{g} / 10 \mathrm{MJ})$ is high.

The consumer's possibilities to reduce his salt intake are rather limited since the discretionary use of salt is only about a third of the total sodium intake. The role of the food industry and catering has grown rapidly during the last few decades and the requirements concerning their products have increased accordingly. If salt intake reduction in the whole population will be considered seriously, changes in the salt content of foodstuffs will have to be made also by the food industry and catering. Some minor changes have already taken place. The salt concentration of soup and gravy mixes has been set at one per cent by legislation, and the salt content of some cheeses and breads have been reduced. However, more effective measures will probably not be taken until the health effects of salt intake reduction at the population level have been clarified.

Acknowledgements. This study was supported by the National Research Council for Agriculture and Forestry in Finland. The cooperation of Dr. Ritva Seppänen (Social Insurance Institution of Finland) in the analyses of the mobile clinic nutrition survey data is gratefully acknowledged.

\section{References}

ANON. 1977. Dietary goals for the United States. Select Committee on Nutrition and Human Needs, United States Senate. 79 p. U. S. Government Printing Office, Washington, D. C.

- 1978 a. Arterial hypertension. Report of a WHO Expert Committee. Techn. Rep. Ser. No 628. 58 p. WHO, Geneva.

- 1978 b. Verenpainetoimikunnan mietintö. Verenpainetaudin ehkäisyn, toteamisen ja hoidon järjestäminen. Komiteanmietintö No 46, 207 p. Helsinki.

- 1979 a. Evaluation of the health aspects of sodium chloride and potassium chloride as food ingredients. Select Committee on GRAS Substances, Food and Drug Administration. 69 p. Life Sciences Research Office, Federation of American Societies for Experimental Biology, Bethesda, Maryland.

- 1979 b. Joukkoruokailututkimus 21. Yhteenveto ja tulosten hyödyntämisestã saatuja kokemuksia. SITRA. 92 p. Kyriiri Oy, Helsinki.

- 1979 c. Kotitaloustiedustelu 1976. Osa III. Tilastollisia tiedonantoja No 62. 107 p. Tilastokeskus, Helsinki.

- 1979 d. Sodium, chlorides, and conductivity in drinking-water. Report of a WHO Working Group. EURO Reports and Studies No 2. 63 p. WHO, Copenhagen.

- 1981 a. Ravintotaselaskelmat vuodelta 1980. Ennakkotiedot. Maatalouden taloudellinen tutkimuslaitos. 4 p. Helsinki. 
- 1981 b. Ravitsemustoimikunnan mietintō. Selvitys ravinnon ja terveyden välisistä yhteyksistã sekä suositukset suomalaisen kansanravitsemuksen parantamiseksi. Komiteanmietintō No 30.143 p. Helsinki.

- 1981 c. Salt in the diet. British Nutrition Foundation. Briefing paper No 2. Nutr. Bull. 6: 171-188.

- 1981 d. Selvitys suolan käytöstä kotimaisessa elintarviketeollisuudessa. Julkaisemattomat tiedot. Elintarviketeollisuusliitto, Helsinki.

HANNUKAINEN, E. 1981. Makkaran ja lihan kulutus ja merkitys ravintona Suomessa tällã vuosisadalla. Helsingin yliopiston lihateknologian lait. julk. No 274. 173 p.

HIILESMAA, V. A. 1977. Jodiprofylaksin alkuvaikeuksia ja tuloksia. Suom. lääk I. 32: 1404-1408.

MORGAN, T., MYERS, J. \& CARNEY, S. 1979. The evidence that salt is an important aetiological agent, if not the cause, of hypertension. Clin. Sci. 57: 459s-462s.

PIETINEN, P., RUOTSALAINEN, P., TANSKANEN, A. \& PUSKA, P. 1981: Sodium intake reduction in volunteer families by using a salt substitute and nutrition counselling. Ann. Nutr. Metab. in press.

SALOVAARA, H. 1981. Suolan käyttö viljavalmisteissa. Tausta-artikkeli Elintarvikkeiden tutkimussäätiön järjestämässä seminaarissa Suola ruokavaliossamme. 8 p. Elintarvikkeiden tutkimussäätiö, Helsinki.

SEPPÄNEN, R., HASUNEN, H. \& PEKKARINEN, M. 1981. Ruoankäyttö ja ravinnonsaanti Suomessa 1973-1976. Autoklinikan ravintotutkimuksen seuranta. (Summary: The food consumption and nutrient intake in Finland from 1973 to 1976). Kansanel. lait. Julk. NL:22. 183 p. Helsinki.

SIMPSON, F. O. 1979. Salt and hypertension: a sceptical review of evidence. Clin. Sci. 57: 463s-480s.

TUOMILEHTO, J., PUSKA, P., TANSKANEN, A., KARPPANEN, H., PIETINEN, P., NISSINEN, A., ENLUND, H. \& RUOTSALAINEN, P. 1981. A community-based intervetion study on the feasibility and effects of the reduction of salt intake in North Karelia, Finland. Acta Cardiol. 36: 83104.

- , RAJALA, A.-L., TIKKANEN, J., PIETINEN, P. \& KARPPANEN, H. 1978. Ruokasuolan käytön yhteys verenpaineeseen. Hallinto ja terveys 5: 409-416.

VARO, P. 1981. Kivennäisainetaulukko. Second. Ed. 118 p. Otava, Helsinki.

WESTIN, S. 1980. Genomsnittlig konsumtion av natrium och klorid. Vår Föda 32: 321-325.

Ms received October 16, 1981.

\section{SELOSTUS}

\section{Natriumin lähteet suomalaisessa ruokavaliossa}

\section{Pirjo Pietinen}

Helsingin yliopiston ravitsemustieteen laitos, 00710 Helsinki 71.

Tämän selvityksen tarkoituksena oli saada kokonaiskuva suomalaisen ruokavalion sisältämästä luonnollisesta natriumista ja lisätystä ruokasuolasta. Laskelmien pohjana käytettiin elintarvikkeiden kulutuslukuja, ruokasuolan myyntilukuja, elintarviketeollisuuden antamia tietoja suolan käytöstä ja kansaneläkelaitoksen autoklinikkatutkimuksen yhteydessä v. 1973-76 suoritetun ravinnonkäyttōtutkimuksen tuloksia.

$\mathrm{L}$ isätyn ruokasuolan saanti on $10-11 \mathrm{~g}$ henkeä kohti vuorokaudessa. Tämän lisäksi saadaan ruoka-aineissa luonnostaan olevaa natriumia noin $0.6 \mathrm{~g}$ eli $1.5 \mathrm{~g} \mathrm{NaCl}$. Suolan kokonaissaanti on siis $11-12 \mathrm{~g}$. Aikuisilla miehillä saanti on 12-15 g:n ja naisilla $10-12 \mathrm{~g}: \mathrm{n}$ tasoa. Ruokavalion suolapitoisuus on keskimäärin $4.3 \mathrm{~g}$ $\mathrm{NaCl} / 1000 \mathrm{kcal}(10.3 \mathrm{~g} / 10 \mathrm{MJ})$ ja aikuisilla $4.5 \mathrm{~g} / 1000 \mathrm{kcal}(10.6 \mathrm{~g} / 10 \mathrm{MJ})$.

Natriumin kokonaissaannista $50 \%$ tulee elintarviketeollisuuden ja joukkoruokailun käyttämästä ruokasuolasta, $38 \%$ kotitalouksien kāyttämästā ruokasuolasta lopun $12 \%$ ollessa ruoka-aineiden luonnollista natriumia. Itse ruokasuolasta $57 \%$ on elintarviketeollisuuden ja joukkoruokailun lisäämää ja 43 \% kuluttajan itsensã lisäämãä. Eri elintarvikeryhmistä ruoka- ja kahvileipien suola muodostaa $22 \%$ natriumin kokonaissaannista makkaran ja muiden lihajalosteiden osuuden ollessa $14 \%$ ja ruokaleivän $16 \%$. Kotitalouksissa käytetystã ruokasuolasta noin puolet käytetään liharuokien valmistukseen ja noin viidennes leivontaan. 